\title{
DESIGN-LED APPROACH TO ENTREPRENEURSHIP
}

\author{
Grzegorz Baran* (ํ) http://orcid.org/0000-0003-2480-8058
}

\begin{abstract}
Background. The literature on entrepreneurship indicates the lack of a strong theoretical basis to fully describe and explain this extremely dynamic and future-oriented area. The classic approaches to the organization and management are not always sufficient to solve some wicked problems in the area, which require the interdisciplinary synthesis of various sciences combined with the experience of practice, and often quite new conceptual frameworks.
\end{abstract}

Research aims. The purpose of this paper is to describe and present the result of the analysis of the relatively new approach to entrepreneurship, which derives from design sciences.

Methodology. The discussion undertaken in the paper is theoretical and methodological, and primarily based on the method of deduction, which referred to the critical literature study has allowed to achieve the research goals.

Key findings. The paper presents the relatively new approach to entrepreneurship, which derives from design sciences and designers' practice. However, it is being successfully adopted within organization and management sciences to solve open, complex and unambiguous management problems, especially where entrepreneurship and innovation are required. As the result of the reasoning process, the basic rules of design-led approach to entrepreneurship have been identified. They constitute the basis for a conceptual framework of the presented approach.

Keywords: entrepreneurship, design-led approach, design thinking, method, methodology.

JEL Codes: O3, M1, L2

* Jagiellonian University, The Faculty of Management and Social Communication, Łojasiewicza 4, Kraków 30-348, Poland. E-mail: g.baran@uj.edu.pl 


\section{INTRODUCTION}

Disruptive changes in the contemporary environment requires organizations to revisit traditional assumptions about how businesses create and capture value (Teece, 2010; Bucolo \& Wrigley, 2012). Changes in how businesses create and capture value are the business essence of entrepreneurship and innovation. Design-led approach delivers a new scientific framework for the description, explanation and design of these processes and their results (Kelley \& Littman, 2001; Huff, Tranfield \& Aken, 2006; Gasparski, 2007; Owen, 2007; Brown, 2008, 2016; Ehn, 2008; Kimbell, 2011, 2012; Bucolo \& Wrigley, 2012; Bucolo, Wrigley \& Matthews, 2012; Sobota \& Szewczykowski, 2014).

\section{Goals and focus}

Although entrepreneurship research has grown in its scope, rigor and impact, and as a field enjoys academic acceptance and legitimacy (Wiklund et al., 2018), the contemporary science of entrepreneurship needs to deal with some scientific and methodological problems that require some interdisciplinary synthesis of the various disciplines combined with the experience of practice. The classic approaches to the organization and management theory are not sufficient to describe and explain the problems, as well as solve some wicked problems in the area of entrepreneurship practice. Thus, new ways of solving the problems and scientific approaches to their description and analysis are needed.

The purpose of this paper is to present, describe and present the result of the analysis of the relatively new approach to entrepreneurship, which derives from design and is understood both as a science and practice within organization and management sciences.

The analysis of literature on entrepreneurship and different approaches to entrepreneurship indicates the lack of a theoretical basis that is strong enough to fully describe and explain this extremely dynamic area of this human activity referring primarily to the unknown future. Historical analysis of the achievements of entrepreneurship has some significance, but in the case of entrepreneurship, it is crucial to study processes that, although start here and now, must look 
ahead. Focusing research only on the past while the practice concerns the use of opportunities in the future that today only vaguely draw, raises the extensive relevance gap between entrepreneurship science and practice.

According to S. Schane and V. Venkataraman:

(...) to date, the phenomenon of entrepreneurship has lacked a conceptual framework. In this note we draw upon previous research conducted in the different social science disciplines and applied fields of business to create a conceptual framework for the field (Shane \& Venkataraman, 2000, p. 217).

Although much has changed since then, we still need to look for new conceptual frameworks, concepts and categories that will allow us to better describe and explain a set of empirical phenomena and predict outcomes not explained or predicted by already existing conceptual frameworks.

\section{Materials and methods}

The discussion undertaken in the paper is theoretical and methodological. This is the attempt of theoretical research based on reasoning related to existing theoretical findings aimed at building the basis of new theory. Theory here is understood as "a statement of relations among concepts within a boundary set of assumptions and constraints. It is no more than a linguistic device used to organize a complex empirical world" (Bacharach, 1989, p. 496). The process of reasoning is the closest to problematization described by M. Alvesson and J. Sandberg (in their influential publication in Academy of Management Review), which is based rather on challenging the assumptions of existing theories than literature gap spotting (Alvesson $\&$ Sandberg, 2011). In such a perspective, the reasoning process itself is mostly implicit and thus difficult to explicitly present in the form of a systematic methodological approach (Dubois \& Gadde, 2002; Shepherd \& Sutcliffe, 2011).

The discussion undertaken in the paper is primarily based on the method of the analysis and criticism of literature on entrepreneurship, design, design-thinking and design-led approach, management sciences (with particular reference to the humanistic field) and methodology of science. 
Due to the methodological perspective adopted in the paper, the literature search is also rather implicit (even in relation to the researcher himself). Alvesson and Sandberg call it a path-defining study. As they claim:

(...) compared to gap-spotting research, problematization efforts are less concerned with covering all possible studies within a field than uncritically reproducing the assumptions informing these studies. Problematization research typically involves a more narrow literature coverage and in-depth readings of key texts, with the specific aim of identifying and challenging the assumptions underlying the specific literature domain targeted (Alvesson \& Sandberg, 2011, p. 256).

Therefore, the literature search was concentrated on those positions, which were the source of the assumptions and constraints the most important for the aim of the reasoning process (not necessarily on current literature presenting valid results of empirical research, which often just reproduce only the existing assumptions from previous papers).

The research method used to solve the scientific problem is mainly deduction, which referred to the critical literature study has allowed to achieve the research goals. However, the applied method comprised a more complex reasoning process that also included elements of analysis, abstraction, synthesis and generalization of existing research results and findings. The reasoning process additionally includes elements of analogy (especially when trying to adapt the design-led approach to entrepreneurship).

In the process of reasoning different ways of reasoning were used at particular stages and in order to achieve individual partial research results. Thus, detailed information on the individual parts of this process is presented in table 1 in the next paragraph, where they are related to the partial research results achieved with their help.

The important axis of the paper are methodological considerations in the sense S. Nowak gives to this term. As he claimed:

(...) description and analysis of the rules of conduct, as well as description and analysis of patterns of products of various research activities is the task of science called the methodology of science (Nowak, 2012, p. 23).

Using the term "approach" in relation to design-led entrepreneurship is to indicate some rules of conduct related to entrepreneurial 
activities. The choice was dictated by the argument of accuracy of the methodological description. According to S. Nowak, we should present methods in such a way that other researchers could more easily use the given method on this basis - in the language of research activities and the methodological rules of conduct that define them or using certain model patterns of products that are their result (Nowak, 2012, p. 23).

\section{LITERATURE REVIEW}

The reasoning process carried out for this paper was preceded by an in-depth literature review. Only a synthetic review of the literature is presented here due to the multiplicity and diversity of definitions of entrepreneurship and the large extent of the design field. It contains only those approaches that are most useful for the purpose of this study. The initial point to present the results of this reasoning contains entrepreneurship and design led approach based largely on design thinking.

\section{Nature of entrepreneurship}

For the reasoning undertaken in this paper, the extensive way of understanding of entrepreneurship presented by A. Koźmiński seems the most adequate. He claims that entrepreneurship is creating something out of nothing based on your own ingenuity, initiative, courage and luck (Koźmiński, 2004, p. 161; Latusek-Jurczak, 2013, p. 31). The adoption of such an approach results directly from the purpose of the research, which is the attempt to adapt the design-led approach to entrepreneurship. The reasoning should therefore begin with the broadest possible scope of the concept of entrepreneurship.

M. Klonowska-Matynia and J. Palinkiewicz (2013) define entrepreneurship also very extensively as the art of dealing with different life situations. On the basis of the literature analysis they state that it was always associated with the search and implementation of new forms of development and change of social status by particularly active individuals, and even entire societies and nations. They point out, based on T. Piecuch (2010, p. 14), to the instrumental dimension 
of entrepreneurship as various forms of activity, such as geographical discoveries, conquests, emigration or finally economic activity (Klonowska-Matynia \& Palinkiewicz, 2013, p. 29). The latter is obviously a particular subject of interest of management science and consequently of this paper.

B. Glinka and S. Gudkova emphasize the multiplicity and diversity of entrepreneurship definitions and they draw attention to the two most frequently cited in the literature (Glinka \& Gudkova, 2011, pp. 18-19). The first is J.A. Timmons' proposition. He described entrepreneurship as "the pursuit of opportunities without taking into account the constraints posed by the currently controlled resources" (Timmons, 1999, p. 329, in: Glinka \& Gudkova, 2011, p. 18). The second is the proposition of S. Shane and S. Venkataraman. They recognize entrepreneurship as:

(...) the processes of discovery, evaluation and exploitation of opportunities for the creation of new goods and services, ways of organizing, markets, processes and resources by organizing efforts in a way that has not occurred before (Shane \& Venkatarman, 2000, in: Glinka \& Gudkova, 2011, p. 19).

In both cases, the emphasis is not so much on an entrepreneur and his unique abilities of the entrepreneur, but especially on the process of discovering and using emerging opportunities. In the second case, this process is consistently ordered and its subsequent stages are indicated. Thus, it fulfills the concept of the method by which T. Kotarbiński understood "a systematically used means, i.e. the course of some action, and thus the composition and configuration of its stages" (Kotarbiński, 1981, p. 524, in: Lisiński, 2016, p. 24). Entrepreneurship is therefore not only a practical activity, but it can be treated as a method and as such can be the subject of scientific research. It is extremely important not to worry about the existing limitations, including the current availability of resources, as mentioned in J. Timmons' notion (1999) and an attempt to overcome the limitations by organizing efforts in an innovative way, as emphasized by S. Shane and S. Venkataraman (2000). Although the notion of innovation does not appear directly, entrepreneurship is inseparably connected with them through the search for new resources, ways of organizing activities, products and services, and new markets. Entrepreneurship means overcoming 
current limitations by constantly seeking new ways. It is focused on the future and crossing what seems impossible today. Thus, the design-led approach to innovation proposed here is so promising, which is discussed in the research results further.

Entrepreneurship, as H.E. Aldrich and J.E. Cliff note, is thus "the process by which people discover and exploit new business opportunities, often through the creation of new business ventures" (Aldrich \& Cliff, 2003, p. 575). The role of the individual - the entrepreneur and his competence - is strongly emphasized in the often quoted definition of entrepreneurship developed by EU institutions. In the official documents of the European Union (i.e. Commission proposal for a Recommendation on Key Competences for Lifelong Learning):

(...) entrepreneurship refers to an individual's ability to turn ideas into action. It includes creativity, innovation and risk taking, as well as the ability to plan and manage projects in order to achieve objectives. This supports everyone in day-to-day life at home and in society, makes employees more aware of the context of their work and better able to seize opportunities, and provides a foundation for entrepreneurs establishing a social or commercial activity (European Commission, 2005, p. 17; 2006, p. 4).

This definition is also worth recalling here due to its accuracy and high practical values.

R. Ronstadt (1984, p. 28) defining entrepreneurship draws attention in turn to the necessary element of risk taking in the dimension of capital, time or career in order to give value to a good or service. All this leads to the gradual creation of wealth thanks to the dynamic process of providing and applying appropriate resources and skills (Koźmiński, 2004, p. 163). It unites the individual dimension of entrepreneurship with the postulated by J. Schumpeter in Theory of Economic Development view that entrepreneurship is the basic engine for the development of the capitalist economy (Koźmiński, 2004, pp. 162-163).

The understanding of entrepreneurship adopted in this paper is closest to Shane and Venkatamaran's definition of entrepreneurship as processes by which "opportunities to create future goods and services are discovered, evaluated, and exploited" (Shane \& Venkataraman, 2000, p. 218). They define the field of entrepreneurship as the scholarly examination of these processes (Shane 
\& Venkataraman, 2000, p. 218). The understanding of entrepreneurship proposed by Shane and Venkataraman is still commonly referred to and recognized by current researchers in different areas of entrepreneurship research (Reuber et al., 2018; Su et al., 2017; Tolbert \& Coles, 2018).

Entrepreneurship, especially in the context of research, can also be treated as a method, whose design-led approach gives a specific feature (especially in the dimension of creating innovation). It will be the subject of undertaken here research to create the basis for a conceptual framework. The aspects related to an entrepreneur's person, his entrepreneurial skills and risk-taking issues in the processes of creating new enterprises and wealth are less important here. As Shane and Venkataraman write:

(...) perhaps the largest obstacle in creating a conceptual framework for the entrepreneurship field has been its definition. To date, most researchers have defined the field solely in terms of who the entrepreneur is and what he or she does (Shane \& Venkataraman, 2000, p. 218).

\section{Design-led approach}

Design as approach to both management science and practice is not new (Simon, 1969/1996; Shangraw et al., 1989; Romme, 2003; Gasparski, 2007; Holmström et al., 2009). It is more and more clearly present in the management literature since H. Simon's book entitled The Science of the Artificial (Simon, 1969/1996).

Some authors seem to equate design-led approach with design thinking (Bucolo \& Matthews, 2010; Bucolo, Wrigley \& Matthews, 2012; Bucolo \& Wrigley, 2012; Wright \& Wrigley, 2019). Design thinking seems be a way of reasoning and acting in practice while designing solutions to specific problems (i.e. goods, services, interactions, organizations, strategies) (Kimbell, 2011; Kelley \& Kelley, 2015; Wszołek \& Grech, 2016). Design-led approach adapts this way of reasoning as a conceptual framework to describe and explain the processes of design thinking as empirical phenomena and refers to an emerging research agenda (Bucolo \& Wrigley, 2012). However, there is no use of such distinction in this paper. Design thinking and design-led approach can be treated interchangeably and complementary. 
According to J. van Aken, "there are serious doubts about the actual relevance of present-day management theory as developed by the academic community" (Aken, 2004, p. 219). The fundamental reason, why new theoretical approaches in management field are needed, is the problem of relevance to practice (Aken, 2004; Huff et al., 2006). Such arguments may be relevant also to entrepreneurship field. Thus, the proposition of design-led approach to entrepreneurship definitely require a deeper analysis and a broader description.

According to S. Bucolo, C. Wrigley and J. Matthews:

(...) the value that design thinking brings to an organization is a different way of framing situations and possibilities, doing things, and tackling problems: essentially a cultural transformation of the way it undertakes its business (Bucolo, Wrigley \& Matthews, 2012, p. 18).

Design thinking is a platform that links "traditionally understood design" with management and social sciences, and their practical applications (Johansson-Sköldberg et al., 2013; Sobota \& Szewczykowski, 2014; Brown, 2016).

According to T. Brown, design thinking is "a methodology that imbues the full spectrum of innovation activities with a human-centered design ethos" (Brown, 2008, p. 86). It can be defined as an approach, methodology or even philosophy of creative thinking and doing that originates from the work of the best designers, architects, engineers and is currently used to solve a much wider than traditionally range of problems. According to K. Dorst, design thinking has been gaining popularity as a new exciting paradigm of coping with problems in sectors which are so distant from each other as IT, business, education, medicine (Dorst, 2011, p. 521). It is an effective approach to creative, innovative and systematic ways of solving open, complex and unambiguous management problems (Liedtka \& Ogilvie, 2011; Brown, 2016). According to D. Sobota and P. Szewczykowski, it as a typical example of triggering, intensifying and sustaining creativity in almost all areas of human life (Sobota \& Szewczykowski, 2014, p. 92). As M. Marufu and A. van der Merwe claim, design thinking is "a discipline in which designers exploit their own knowledge and skills; matching them with consumer needs to come up with technologically feasible products and services" (Marufu \& van der Merwe, 2019, p. 500). 
What is important for entrepreneurship and the purpose of this study, design led approach often enables a strong engagement with customer's emotions, both at the product level and within a new business model (Bucolo \& Wrigley, 2012, p. 2). The results of entrepreneurship are not only new products but also new ventures (Aldrich \& Cliff, 2003, p. 575). Both need often new innovative business models to exploit new business opportunities. As S. Bucolo and C. Wrigley note, design led approach offers various tools and methods for designing, which take into account emotional experiences from an industry perspective (Bucolo \& Wrigley, 2012, p. 2). Design led approach by including thinking typical for designers expands the business perspective not only with emotional, but also with broadly human-centered qualities. According to E. Sanders and P. Stappers, manufacturing enterprises are becoming more and more open to approaches which define product based on human needs (Sanders \& Stappers, 2008, p. 5). This kind of thinking and acting is, as T. Brown writes, "not only human-centred; it is deeply human in and of itself" (Brown, 2016, p. 37).

\section{RESULTS}

In the paper, the reasoning process leading to identification of design-led approach to entrepreneurship was carried out. As the result of the process, the basic rules of design-led approach to entrepreneurship have been identified. They constitute the basis for a conceptual framework of the presented approach. These rules are the main part of the research results. Table 1 summarizes the results. The first two columns of the table 1 show the individual rules and their description. The third column shows scientific methods that were used to formulate the rules.

The rules presented above constitute a conceptual framework of the presented approach and are helpful in understanding its nature. A more detailed description, explanation and attempt to assess the reasoning carried out will be presented in the discussion and conclusion section. 


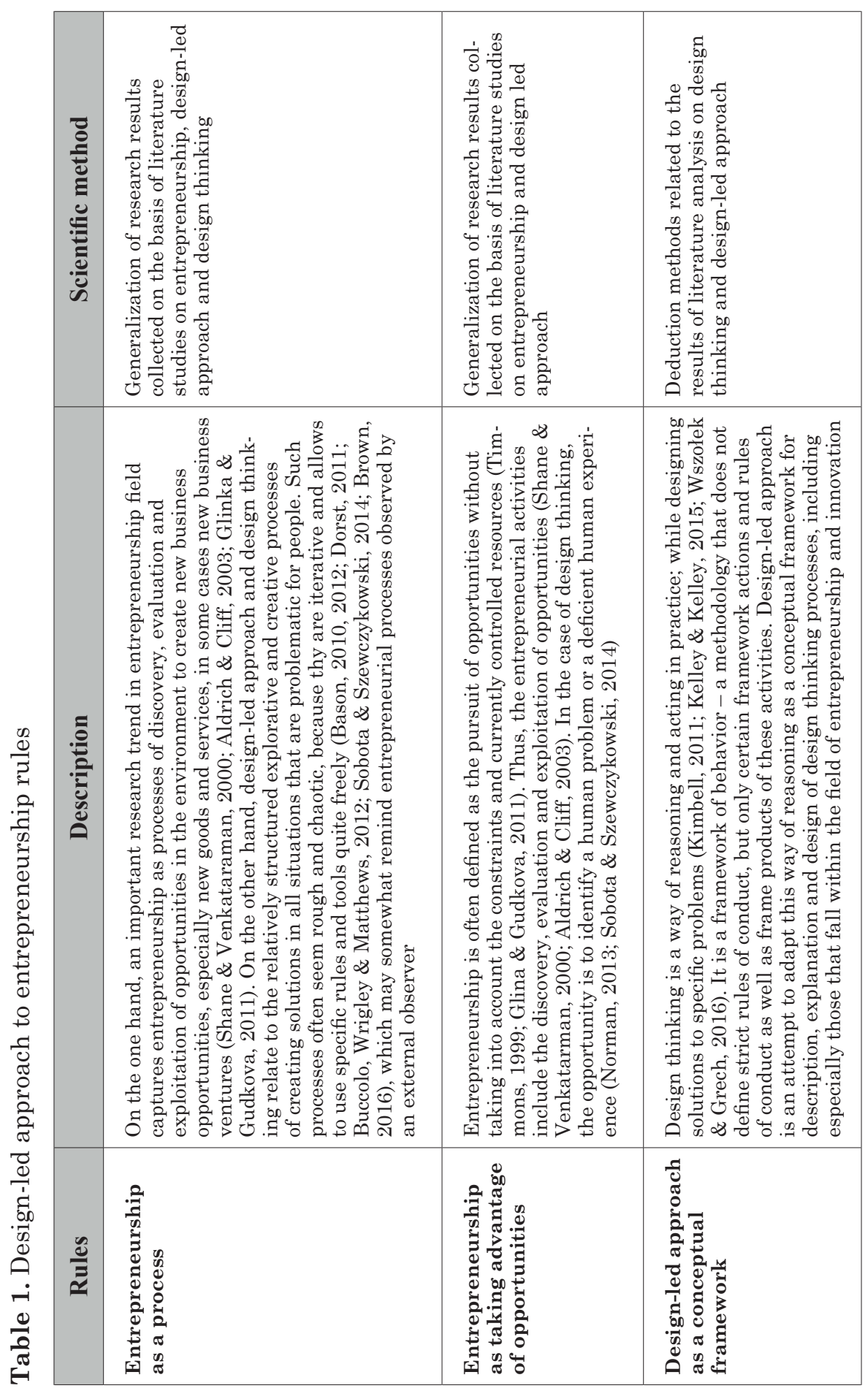




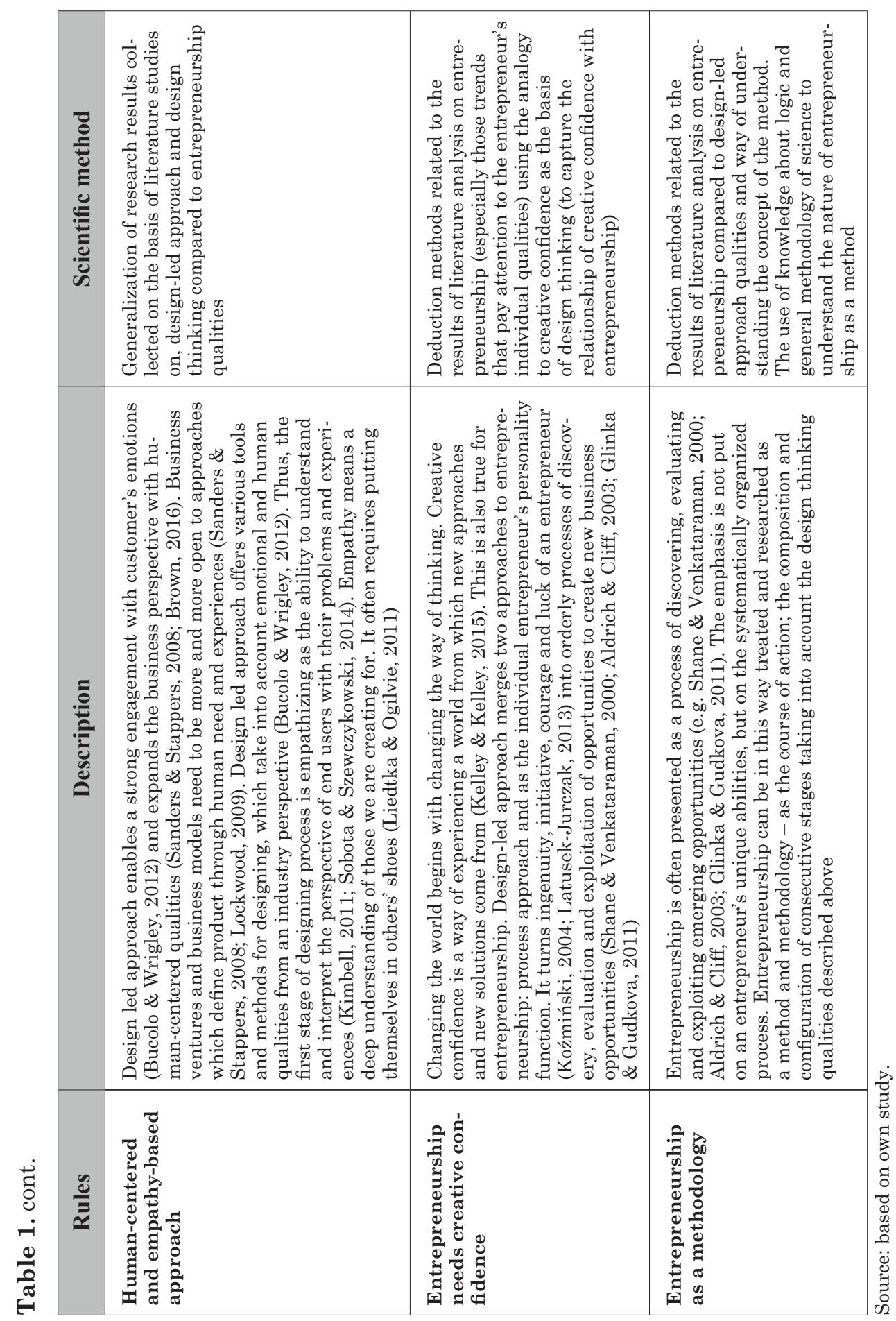




\section{DISCUSSION AND CONCLUSIONS}

Entrepreneurship as a certain property can be referred to both people and activities. In other words, we can call entrepreneurial both a person who carries out specific activities and the actions themselves. Entrepreneurship is then, on the one hand, a certain set of specific personality traits, predispositions and attitudes towards the environment, especially the opportunities and threats occurring in it. Thus, it is a certain potential or readiness for active and innovative action aimed at changing the status quo. In this sense, the creative confidence as one of the rules of design led approach (indicated in table 1) is necessary. The creative confidence is one of central concepts in design thinking (Kelley \& Kelley, 2015; Brown, 2016). T. Kelley considers it as one of the most valuable resources necessary to innovative and effective activity (Kelley \& Kelley, 2015, p. 23-27). T. Brown writes about creative energy and creative power (Brown, 2016). This reminds Koźmiński’s approach to entrepreneurship, which is based on own ingenuity, initiative, courage and luck (Koźmiński, 2004, p. 161; Latusek-Jurczak, 2013, p. 31). Such actions certainly require creative confidence, which, according to T. Kelley and D. Kelley, gives the strength in reaching beyond the status quo (Kelley \& Kelley, 2015, p. 34).

On the other hand, it is not possible to pursue entrepreneurship without taking the creative and innovative activities, which are often the implementation of new and bold ideas, withstanding the difficulties and taking advantage of emerging opportunities. This requires looking at entrepreneurship as a process leading to the achievement of specific results that can be intentionally organized and managed. Numerous researchers understand entrepreneurship in this way - as processes of discovery, evaluation and exploitation of (business) opportunities (Timmons, 1999; Shane \& Venkataraman, 2000; Aldrich \& Cliff, 2003; Koźmiński, 2004; Glinka \& Gudkova, 2011; Reuber, 2018).

The both dimensions are closely related. Entrepreneurial predispositions without the courage to undertake entrepreneurial activities are not enough to create an entrepreneur. Thus, entrepreneurship is often considered in three inseparably related aspects: as an attitude, behavior and process (Klonowska-Matynia \& Palinkiewicz, 2013, p. 30). K. Wach, recalling the typology of H. Landström, divides entrepreneurship as an academic discipline into: entrepreneurship 
as a function of the market, entrepreneurship as a function of an individual entrepreneur and entrepreneurship as a process (Wach, 2013, p. 247; Landström, 2010, p. 11-13).

$\mathrm{K}$. Wach adds to this two further functions indicated in the literature: entrepreneurship as a function of personality and as a function of micro, small and medium enterprises (Wach, 2013, p. 247). A comment expressing some doubt seems necessary at this point. Assuming that processes can be carried out by individuals, teams and entire organizations, the division proposed above is not disjunctive. Entrepreneurship as a process includes both individual managerial activities carried out within larger organizations as well as all processes carried out by micro, small and medium enterprises. Entrepreneurship as a function of micro, small and medium enterprises can be considered from the point of view of processes implemented to achieve certain entrepreneurial goals, as well as market functions by those entities being filled in.

Simplifying the dvision proposed above for the needs of the reasoning conducted here, the two categories are the most important: process approach to entrepreneurship and entrepreneurship as the the individual entrepreneur's personality function. Entrepreneurship as a process is most interesting form the management sciences point of view and the reasoning process undertaken here. Landström divided this approach into: processes leading to the creation of new entities and processes leading to the discovery of opportunities (Landström, 2010, p. 11-13; Wach, 2013, p. 247). Design led approach to entrepreneurship seems to merge process approach with entrepreneurship as the individual entrepreneur's personality function (table 1, section: "Entrepreneurship needs creative confidence"). It turns individual entrepreneur's qualities into systematic processes of discovery, evaluation and exploitation of business opportunities.

Recognizing entrepreneurship as a process, we should bear in mind that it should be not understood narrowly as a function of managerial activities as proposed by K. Wach (2013, p. 247). It is rather a function of diagnostic and design activities determined by a certain design methodology and mindset, as M. Wszołek and M. Grech define design thinking (Wszołek \& Grech, 2016, p. 12-13). Entrepreneurship can be less the function of personality, and more the result of systematic approach. Design thinking and design-led approach refer especially to the methodology, which is based on the unique, typical for designers work culture (Brown, 2008; Wszołek \& Grech, 2016). 
The basis of such processes is not the result of artistic soul or a glimpse of genius, but systematic implementation of certain specific activities: (1) research and diagnostic activities based on empathy (table 1, section: "Human-centered and empathy-based approach"); (2) creative activities based on team work and heuristic methods, (3) experimenting with ideas and transforming the most promising ones into prototypes of future solutions, (4) improving prototypes so that they could be implemented as new products (Kelley \& Littman, 2001; Sobota \& Szewczykowski, 2014).

Entrepreneurship in the design-led approach is not something ephemeral, barely perceptible, but the set of rules of conduct and their results. Such a sketched view of entrepreneurship is the premise for capturing it in a solid methodological framework. As it has already been mentioned above, the tasks of the methodology include the description and analysis of the rules of conduct as well as the description and analysis of the patterns of products of research activities (Nowak, 2012 , p. 23). Thus, entrepreneurship in the design-led approach can be treated as a method and even a methodology. A method as a set of rules of conduct, including research activities and a methodology as their description and analysis.

Entrepreneurship in this approach is however examined as a method and methodology recognized less as strict rules of conduct, and more as a conceptual framework of reasoning and acting, and the frame results of those activities (table 1, section: "Design-led approach as a conceptual framework" and section: "Entrepreneurship as a methodology"). Entrepreneurship recognized in this way is not only a practical activity, but also a method in the sense that Kotarbiński has given to this concept: a systematically used means shaping the course of action (Kotarbiński, 1981). Such an understanding of entrepreneurship gives not only new research opportunities, but also has great practical advantages. We do not leave entrepreneurship at the grace of exceptional qualities and skills of outstanding individuals in this field, but we assume that it is a repetitive method, so everyone can learn it. And as a method it can be the subject of methodological considerations.

These conclusions are coherent with K. Wach's findings. Considering whether entrepreneurship is science or art, he raised the question of whether it can be effectively taught. Contemporary research proves that just like medicine (to which similar doubts are raised), it can be effectively taught as a practice (Wach, 2013, p. 248). Design-led 
approach to entrepreneurship is not only a practice, but also practical science or design science as H. Simon called the whole group of practical disciplines, including organization and management sciences (Simon, 1996; Gasparski, 2007). Design sciences provide knowledge that can serve as a premise for building projects that are the specialty of those who professionally deal with designing and shaping organizations. Such knowledge is based both on the results of theoretical/explanatory sciences and the analysis of previously designed solutions (Gasparski, 2007, p. 38).

\section{SUMMARY AND FURTHER RESEARCH DIRECTIONS}

The best summary of the paper that is an outline of a certain approach to entrepreneurship (design-led approach) formulated primarily on the basis of deduction methods related to the literature study is to indicate further directions of research. The further research should (1) allow an empirical verification of the formulated conclusions, (2) better describe and explain the presented approach.

The rules of design-led approach presented in the results have been inferred from the previous findings presented in the scientific literature on entrepreneurship, design thinking and design-led-approach. Each of the rules requires further empirical research focused on selected entrepreneurial processes. The analysis of entrepreneurial processes will allow not only to verify the findings, but also to check whether there are other rules relevant to the design-led approach to entrepreneurship.

These studies should be carried out taking into account the principles of design sciences field. Entrepreneurship is a practical science. It means that its knowledge is applied in practice and is created on the basis of the evaluation of this application. R. Razzouk i V. Shute accurately capture this relationship:

In many fields, knowledge is generated and accumulated through action (i.e., doing something and evaluating the results). That is, knowledge is used to produce work, and work is evaluated to produce knowledge (Razzouk \& Shute, 2012, p. 333).

Thus, an interesting direction of research would be an attempt to apply the rules identified here in practice, to then observe the results achieved. 
Entrepreneurship science is strongly dependent on the practice of entrepreneurship. It is not possible to create entrepreneurial theories in isolation from what the entrepreneurs do. And it is not only that entrepreneurship is an empirical science, so the results of scientific research must be verified (or falsified) empirically. It is primarily about the property indicated above, which means that knowledge in an entrepreneurship field is created through action. As S. Nowak states, in the case of practical sciences, the truth of claims is irrelevant. They must provide the most reliable means of achieving certain practical goals (Nowak, 2012, p. 20). Just as there is no entrepreneurship outside the action, there is no knowledge of entrepreneurship other than referred to the activity.

\section{REFERENCES}

Aken, J.E.V. (2004). Management research based on the paradigm of the design sciences: The quest for field-tested and grounded technological rules. Journal of Management Studies, 41(2), 219-246.

Aldrich, H.E. \& Cliff, J.E. (2003). The pervasive effects of family on entrepreneurship: Toward a family embeddedness perspective. Journal of Business Venturing, 18(5), 573-596.

Alvesson, M. \& Sandberg, J. (2011). Generating research questions through problematization. Academy of Management Review, 36(2), 247-271.

Bacharach, S.B. (1989). Organizational theories: Some criteria for evaluation. Academy of Management Review, 14(4), 496-515.

Bason, C. (2010). Leading Public Sector Innovation: Co-creating for a Better Society. Bristol: The Policy Press.

Bason, C. (2012). Designing co-production: Discovering new business models for public services. In: Leading Innovation through Design: Proceedings of the DMI 2012 International Research Conference (pp. 309-322). Boston (MA): DMI.

Brown, T. (2008). Design thinking. Harvard Business Review, 86(6), 84-92.

Brown, T. (2016). Zmiana przez design: Jak Design Thinking zmienia organizacje i pobudza innowacyjność. Wrocław: Instytut Dziennikarstwa i Komunikacji Społecznej Uniwersytetu Wrocławskiego.

Bucolo, S. \& Matthews, J.H. (2010). Using a design led disruptive innovation approach to develop new services: Practising innovation in times of discontinuity. In: Proceedings of the 11th International CINet Conference: Practicing Innovation in the Times of Discontinuity (pp. 176-187). Zurich: CINet. 
Bucolo, S. \& Wrigley, C. (2012). Using a design led approach to emotional business modelling. In: Leading Innovation through Design: Proceedings of the DMI 2012 International Research Conference (pp. 323-333). Boston (MA): DMI.

Bucolo, S., Wrigley, C. \& Matthews, J. (2012). Gaps in organizational leadership: Linking strategic and operational activities through design-led propositions. Design Management Journal, 7(1), 18-28.

Dorst, K. (2011), The core of 'design thinking' and its application. Design Studies, 32(6), 521-532.

Dubois, A. \& Gadde, L.E. (2002). Systematic combining: An abductive approach to case research. Journal of Business Research, 55(7), 553-560.

Ehn, P. (2008). Participation in design things. In: Proceedings of the Tenth Anniversary Conference on Participatory Design 2008 (pp. 92-101). Indianapolis (IN): Indiana University.

European Commission (2005). Commission proposal for a Recommendation on Key Competences for Lifelong Learning. COM(2005) 548 Final. Brussels. 10th Nov 2005.

European Commission (2006). Communication from the Commission to the Council, the European Parliament, the European Economic and Social Committee and the Committee of the Regions, Implementing the Community Lisbon Programme: Fostering entrepreneurial mindsets through education and learning. $\mathrm{COM}(2006) 33$ Final. Brussels. 13th Febr 2006.

Gasparski, W. (2007). Wiedza o organizacji i zarządzaniu oraz jej poznawcze ugruntowanie. Wspótczesne Zarzqdzanie, 1, 34-47.

Glinka, B. \& Gudkova, S. (2011). Przedsiębiorczość. Warszawa: Wolters Kluwer.

Holmström, J., Ketokivi, M. \& Hameri, A.P. (2009). Bridging practice and theory: A design science approach. Decision Sciences, 40(1), 65-87.

Huff, A., Tranfield, D. \& van Aken, J.E. (2006). Management as a design science mindful of art and surprise: A conversation between Anne Huff, David Tranfield, and Joan Ernst van Aken. Journal of Management Inquiry, 15(4), 413.

Johansson-Sköldberg, U., Woodilla, J. \& Çetinkaya, M. (2013). Design thinking: past, present and possible futures. Creativity and Innovation Management, 22(2), 121-146.

Kelley, D. \& Kelley, T. (2015). Twórcza odwaga. Tłum. A. Doroba. Warszawa: Wyd. MTBiznes.

Kelley, T. \& Littman, J. (2001). The Art of Innovation: Lessons in Creativity from IDEO, America's Leading Design Firm. New York: Doubleday.

Kimbell, L. (2011). Rethinking design thinking: Part 1. Design and Culture, 3(3), $285-306$. 
Kimbell, L. (2012). Rethinking design thinking: Part 2. Design and Culture, 4(2), $129-148$.

Klonowska-Matynia, M. \& Palinkiewicz, J. (2013). Przedsiębiorczość w teorii ekonomicznej. Zeszyty Naukowe Wydziału Nauk Ekonomicznych Politechniki Koszalińskiej, 17, 29-40.

Kotarbiński, T. (1981). Traktat o dobrej robocie. Warszawa: Ossolineum.

Koźmiński, A.K. (2004). Zarzqdzanie w warunkach niepewności. Warszawa: WN PWN.

Landström, H. (2010). Pioneers in Entrepreneurship and Small Business Research. New York: Springer.

Latusek-Jurczak, D. (2013). Polscy przedsiębiorcy w Dolinie Krzemowej. Management and Business Administration: Central Europe, 21(1), 30-40.

Liedtka, J. \& Ogilvie, T. (2011). Designing for Growth. New York: Columbia University Press.

Lisiński, M. (2016). Procedury naukowe indukcji zupełnej i niezupełnej w metodologii nauk o zarządzaniu. Zeszyty Naukowe Uniwersytetu Ekonomicznego w Krakowie, 6(954), 23-46.

Lockwood, T. (2009). Design Thinking: Integrating Innovation, Customer Experience, and Brand Value. New York: Allworth Press.

Marufu, M.A. \& van der Merwe, A. (2019). Using service-dominant logic to build empathy for design thinking in a health service delivery environment. In: Third International Congress on Information and Communication Technology (pp. 499-515). Singapore: Springer.

Norman, D. (2013). The Design of Everyday Things. New York: Basic Books.

Nowak, S. (2012). Metodologia badań społecznych. Warszawa: WN PWN.

Owen, C. (2007). Design thinking: Notes on its nature and use. Design Research Quarterly, 2(1), 16-27.

Piecuch, T. (2010). Przedsiębiorczość: podstawy teoretyczne. Warszawa: C.H. Beck.

Razzouk, R. \& Shute, V. (2012). What is design thinking and why is it important? Review of Educational Research, 82(3), 330-348.

Reuber, A.R. et al. (2018). International entrepreneurship: The pursuit of entrepreneurial opportunities across national borders. Journal of International Business Studies, 49, 395-406.

Romme, A.G.L. (2003). Making a difference: Organization as design. Organization Science, 14(5), 558-573.

Ronstadt, R. (1984). Entrepreneurship. Dover (MA): Lord Publishing.

Sanders, E.B.N. \& Stappers, P.J. (2008). Co-creation and the new landscapes of design. Co-design, 4(1), 5-18.

Shane, S. \& Venkataraman, S. (2000). The promise of entrepreneurship as a field of research. Academy of Management Review, 25(1), 217-226. 
Shangraw R.F. Jr., Crow, M.M. \& Overman, E.S. (1989). Public administration as a design science. Public Administration Review, 49(2), 153-160.

Shepherd, D.A. \& Sutcliffe, K.M. (2011). Inductive top-down theorizing: A source of new theories of organization. Academy of Management Review, 36(2), 361-380.

Simon H. (1969/1996). The Science of the Artificial. Massachusetts: MIT Press.

Sobota, D.R. \& Szewczykowski, P. (2014). Design thinking jako metoda twórczości. Filo-Sofija, 14(27), 91-113.

Su, J., Zhai, Q. \& Karlsson, T. (2017). Beyond red tape and fools: Institutional theory in entrepreneurship research, 1992-2014. Entrepreneurship Theory and Practice, 41(4), 505-531.

Teece, D. (2010). Business models, business strategy and innovation. Long Range Planning, 43(2-3), 172-194.

Timmons, J.A. (1999). New Venture Creation, 5th. ed. Burr Ridge (Ill.): Irwin McGraw-Hill.

Tolbert, P.S. \& Coles, R. (2018). Studying entrepreneurship as an Institution. In: J. Glückler, R. Suddaby, R. Lenz (eds.). Knowledge and Institutions. Knowledge and Space, vol. 13 (pp. 271-299). Cham: Springer.

Wach, K. (2013). Edukacja na rzecz przedsiębiorczości wobec współczesnych wyzwań cywilizacyjno-gospodarczych. Przedsiębiorczość - Edukacja, 9, 246-257.

Wiklund, J., Wright, M. \& Zahra, S.A. (2018). Conquering relevance: Entrepreneurship research's grand challenge. Entrepreneurship Theory and Practice.

Wright, N. \& Wrigley, C. (2019). Broadening design-led education horizons: Conceptual insights and future research directions. International Journal of Technology and Design Education, 29(1), 1-23.

Wszołek, M. \& Grech, M. (2016). Komentarz do wydania 2. In: T. Brown. Zmiana przez design: Jak Design Thinking zmienia organizacje i pobudza innowacyjność (pp. 11-20). Wrocław: Instytut Dziennikarstwa i Komunikacji Społecznej Uniwersytetu Wrocławskiego. 